\title{
En mann i 40-årene med rask forverring av kronisk fotsår
}

NOE Å LAERE AV

\section{THOMAS TETENS MOE}

E-post: thomoe@ous-hf.no Seksjon for hudsykdommer

Oslo universitetssykehus

Thomas Tetens Moe er lege i spesialisering, tidligere i samme stilling ved Hudavdelingen, Stavanger universitetssjukehus.

Forfatter har fylt ut ICMJE-skjemaet og oppgir ingen interessekonflikter.

\section{MARCUS GÜRGEN}

Hudavdelingen

Stavanger universitetssjukehus

og

Kvinesdal legesenter

Marcus Gürgen er spesialist i generell kirurgi og allmennmedisin, overlege ved Sårdiagnostisk senter ved Hudavdelingen, Stavanger universitetssjukehus og fastlege.

Forfatter har fylt ut ICMJE-skjemaet og oppgir ingen interessekonflikter.

\section{ERLING UNDERSRUD}

Avdeling for patologi

Stavanger universitetssjukehus

Erling Undersrud er spesialist i patologi og hudpatologi (ICDP-UEMS) og overlege.

Forfatter har fylt ut ICMJE-skjemaet og oppgir ingen interessekonflikter.

\section{RUNE KLEPP}

Avdeling for radiologi

Stavanger universitetssjukehus

Rune Klepp er spesialist i radiologi og overlege.

Forfatter har fylt ut ICMJE-skjemaet og oppgir ingen interessekonflikter.

\section{HARALD SOLA}

Ortopedisk avdeling

Stavanger universitetssjukehus

Harald Sola er spesialist i ortopedi og overlege.

Forfatter har fylt ut ICMJE-skjemaet og oppgir ingen interessekonflikter.

Ved vurdering av kroniske sår er det viktig at bakenforliggende årsak utredes. Vi beskriver her en pasient som hadde vært plaget med residiverende sår på venstre underekstremitet etter et alvorlig traume i barndommen. Han ble nå henvist på grunn av rask forverring av såret. 
En mann i 40-årene ble henvist til Sårdiagnostisk senter ved et universitetssykehus fordi han de siste månedene hadde hatt tiltagende utvikling av ulcerasjon på venstre hæl ledsaget av så store smerter at han ikke kunne belaste foten. Pasienten var yrkesaktiv og ellers stort sett frisk.

I barnealder var pasienten blitt overkjørt av en lastebil og påført venstresidig åpen proksimal tibiafraktur med omfattende vevsskade ned til benvev på øvre to tredeler av leggen og på foten ned til tærne. I tillegg hadde han fått venstresidig femurskaftfraktur, olecranonfraktur og fraktur av os zygomaticus. På grunn av omfattende skader hadde man umiddelbart vurdert leggamputasjon, men valgt å gå videre med ekstremitetsbevarende behandling, spesielt på grunn av hans unge alder. Rekonstruksjon var blitt gjort via lokale lapper, der man hadde løsnet mediale musculus (m.) gastrocnemius distalt og svingt denne opp over proksimale tredel av tibia. Nedre del av tibia var blitt dekket med nedre del av $\mathrm{m}$. soleus. Bevart hud på legg og fot som var delvis løsnet hadde blitt lagt over musklene som hudtransplantat. Tibiafrakturen var blitt behandlet konservativt i gips, mens femurfrakturen ble behandlet med strekk.

I videre forløp utviklet pasienten en varusfeilstilling i leggen fire år etter skaden, og han ble operert med valgiserende osteotomi. Det samme året tilkom det et ikke-helende sår på hælen, som ble dekket med ny rotasjonslapp fra nedre del av leggen. Dette såret residiverte på nytt, og ni år etter primærskaden ble han igjen operert med en plantar muskellapp for dekking.

Senere utviklet han kronisk residiverende sår, fisteldannelse og lymfødem i området og var i regelmessig kontakt med spesialisthelsetjenesten. Til tross for begrenset funksjon og kronisk sårproblematikk levde han et aktivt liv med familie og full jobb. De siste årene før konsultasjonen ved sårdiagnostisk senter hadde han i stor grad selv utført sårstell og var blitt fulgt opp i primærhelsetjenesten samt hos fysioterapeut.

Ved vurdering av kroniske sår skal bakenforliggende årsak alltid utredes. Første steg vil være anamnese og klinisk undersøkelse, inkludert undersøkelse av blodsirkulasjon ved pulspalpasjon, måling av ankeltrykk og beregning av ankel-arm-indeks. Videre må det gjøres en vurdering av lokale sårforhold, bl.a. om det er kontakt mellom ulcerasjonen og dypere strukturer, slik som leddkapsel, sener og benvev.

Ved klinisk undersøkelse hadde pasienten god arteriell sirkulasjon i begge underekstremiteter med palpabel puls fra lyske til fot og normal kapillærfylning. Ankelarm-indeks målt med ultralyddoppler var 1,22 bilateralt. Den aktuelle ekstremiteten bar preg av muskelatrofi og lymfødem distalt for ankelen. Det var ingen palpabel lymfeknutehevelse fra fot og opp til lyske. Huden bar preg av uttalt arrvev og tidligere transplantert hud både på fot og legg opp til ovenfor kneleddsnivå (Figur 1). Pasienten manglet aktiv fleksjon i ankel over null grader. Hælen fremsto klinisk som deformert med ulcerasjon beliggende i trykkutsatt område. Ulcerasjonen var $13 \times 8 \mathrm{~cm}$ og strakk seg fra dorsalside av hel ned plantart og var omkranset av massive, illeluktende og delvis masererte hyperkeratotiske sårkanter (Figur 2). Sentralt i såret over kalkaneus kom det puss fra et mindre område med svart nekrose. Med sonde ble det påvist en 2,2 cm lang fistulering inn på benvev.

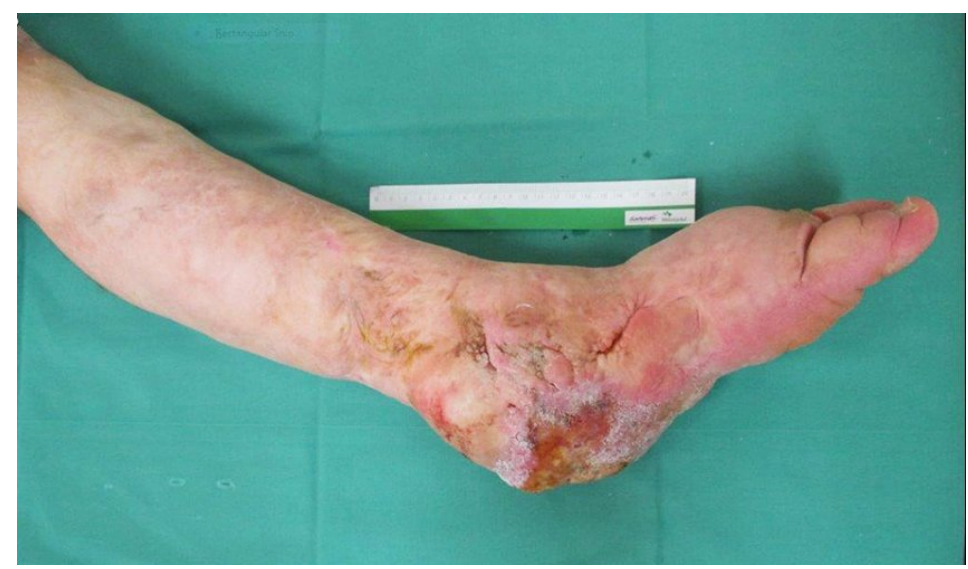


Figur 1 Venstre legg og fot sett medialt ved første konsultasjon. Uttalte arrforandringer etter omfattende tidligere kirurgi. Hcelen er tydelig deformert, mens såret ligger til dels i planta pedis, dels opp mot bakre aspekt av hcelen. Lymfødem ved tcerne og fotrygg.

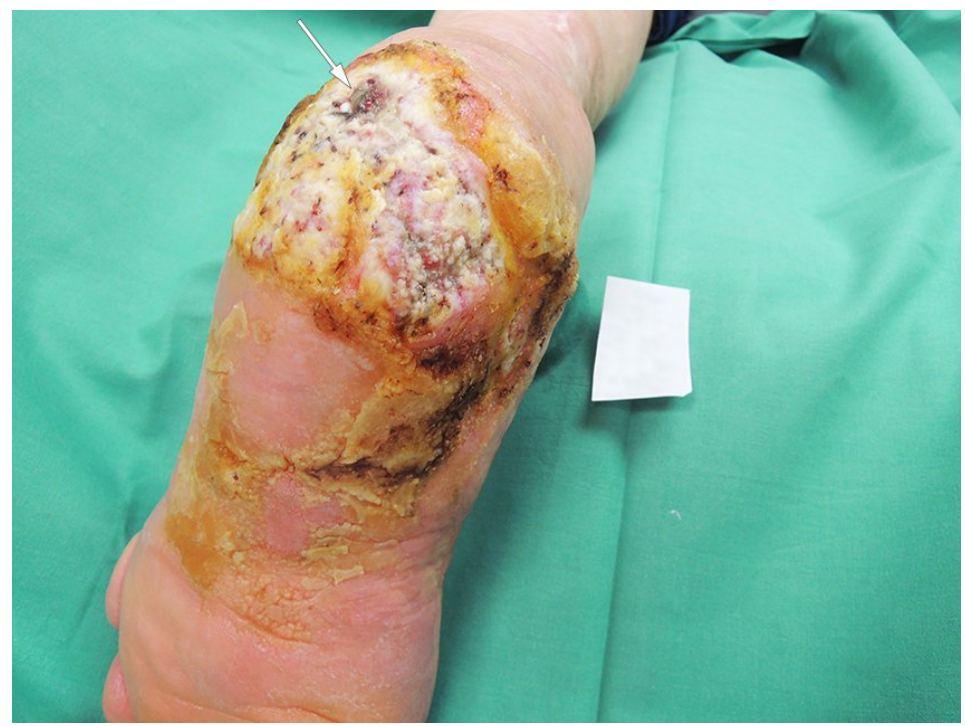

Figur 2 Sårets utseende ved første konsultasjon. Det mørke området øverst er fistelåpningen mot kalkaneus (markert med pil).

Basert på disse funnene ble en arteriell genese vurdert lite sannsynlig. Lukt fra sår oppstår gjerne som følge av bakteriell vekst, og i kreftsår er anaerobe bakterier ofte ansvarlig for dette. Kontakt med benvev talte for osteomyelitt sekundært til sårdannelse. Langvarig underliggende fistulering fra en osteomyelitt er kjent for å kunne forårsake malignitetsutvikling (1). Vi observerte også eksofytisk vekst av vev og sentrale nekroser. Samlet ga dette mistanke om en malign tilstand.

Rundt 4 uker senere kom det svar på tre stansebiopsier fra hhv. lateralt på helen, like ved fistelen og fra bakside av hælen. Disse var ikke konklusive, men viste funn forenlig med verrukøst karsinom.

Verrukøst karsinom kan oppstå ved kronisk inflammasjon plantart mange år etter skade (2). Uavhengig av lokalisasjon er verrukøse karsinomer alltid plateepitelkarsinomer. Slike lesjoner kjennetegnes av eksoendofytisk vekst, der den endofytiske komponenten viser minimal eller ingen sikker cytologisk atypi. Disse karsinomene er dermed usedvanlig høyt differensiert, og ikke mulig å skille fra reaktiv prosess i tidlig fase eller i en overfladisk biopsi. Ved karsinomutvikling er en avhengig av tilstrekkelig dyp biopsi, der en får fremstilt tumors relasjon til dypere deler av underliggende stroma for å stille diagnosen med sikkerhet $(3,4)$.

Røntgenbilde av bakre del av foten viste osteolyse (Figur 3), og magnetisk resonanstomografi viste uttalte bløtdelsforandringer og funn forenlig med osteomyelitt i kalkaneus med margødem i storparten av knokkelen og osteolyse baktil (Figur 4). Begge bildeunders $\varnothing$ kelsene viste en noe deformert kalkaneus som sannsynlig fraktursekvele. Som metastaseutredning ble det gjort ultralydundersøkelse av regionale lymfeknuter, som viste normale lymfeknuter med upåfallende størrelse, ekko og dopplersignal. Med bakgrunn i funn av osteomyelitt ble pasienten henvist til ortoped for benbiopsi til mikrobiologisk undersøkelse. Denne viste ingen vekst av aerobe bakterier, men anaerob dyrkning viste sparsom vekst av Anaerococcus species, Dialister micraerophilus samt rik vekst av Actinomyces turicencis som var sensitv for klindamycin, meropenem, piperacillin/tazobactam, og penicillin G, men resistent for metronidazol. Funnet ble vurdert ved infeksjonsmedisinsk avdeling. Oppvekst av blant annet Actinomyces turicensis ville sannsynligvis kreve langvarig antibiotikabehandling hos denne pasienten. Samtidig hadde man fra infeksjonsmedisinsk side lite tro på at man ville komme i mål med antibiotikabehandling alene. 


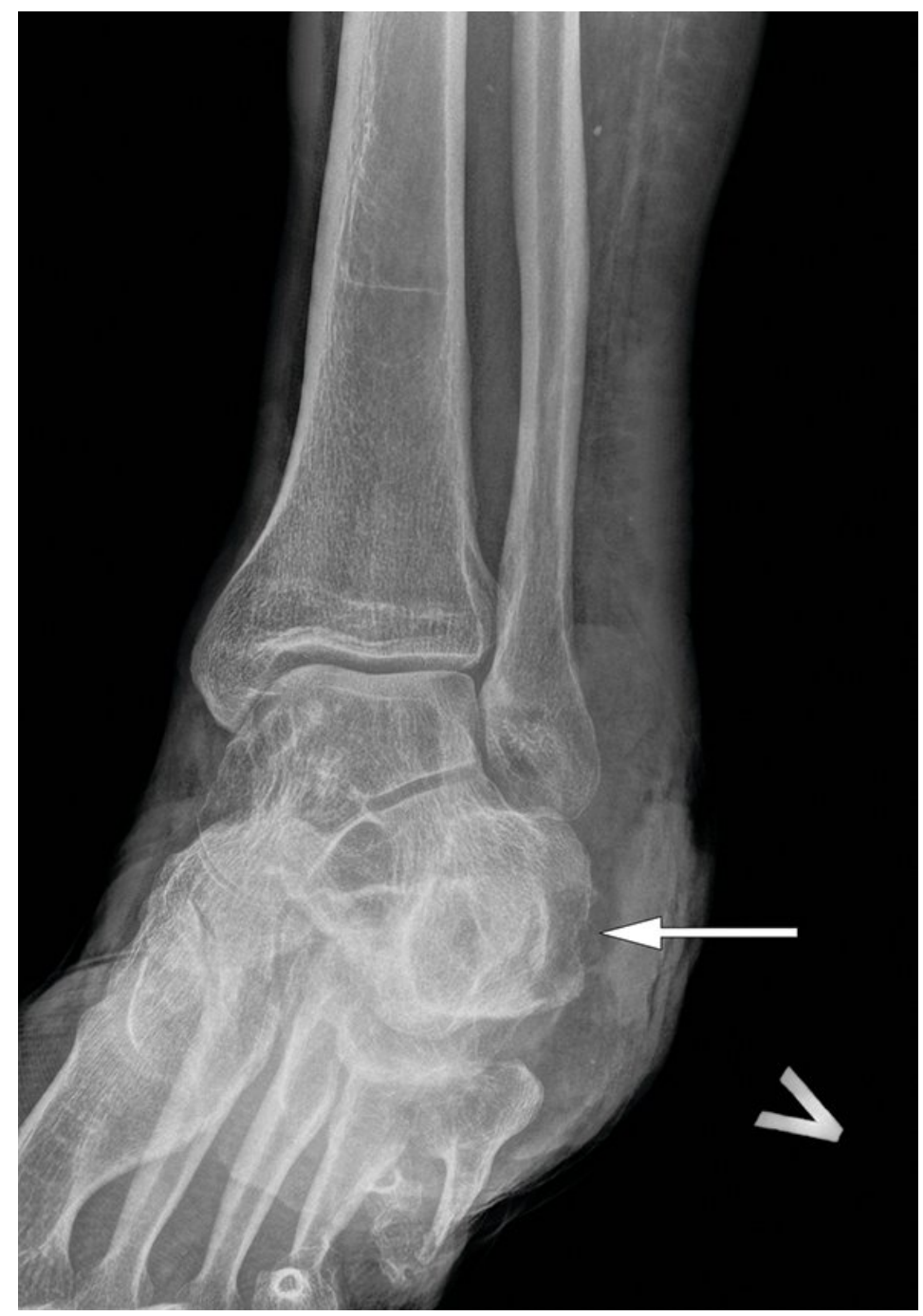

Figur $_{3}$ Røntgenbilde av venstre fot og ankel. Pilen peker mot osteolysen i kalkaneus.

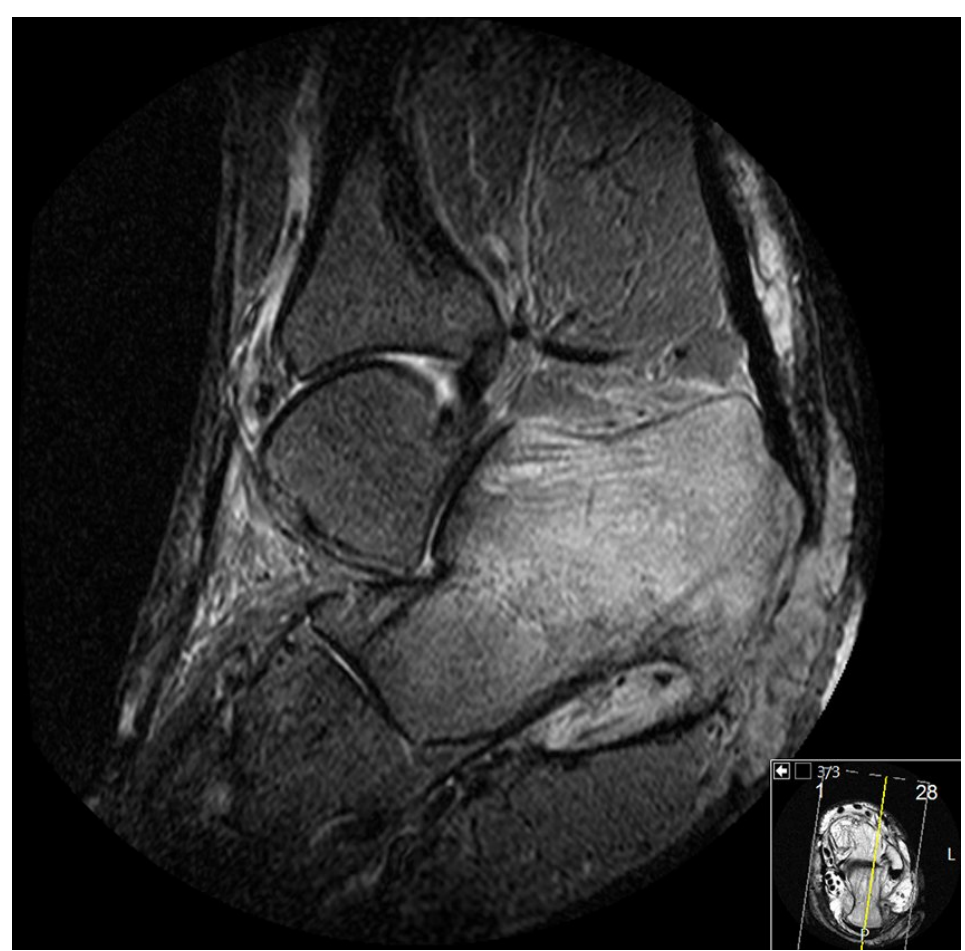

Figur 4 MR-bildet viser utbredt margødem i kalkaneus.

Utredningen så langt bekreftet en pågående kronisk osteomyelitt og ga klinisk og histologisk mistanke om malignitet. Maligne hudsvulster skal i all hovedsak behandles kirurgisk, vanligvis med eksisjon med frie marginer. Ved absolutt eller relativ kontraindikasjon for kirurgi kan strålebehandling i palliativ hensikt benyttes. Kronisk 
osteomyelitt skal behandles med antibiotika på grunnlag av sensitivitetsmønster, men det vil ofte være behov for kirurgisk revisjon av infisert og nekrotisk benvev.

Vi trengte dypere biopsier for histologisk å kunne bekrefte diagnosen plateepitelkarsinom, og osteomyelitt måtte behandles. Flere behandlingsmodaliteter ble vurdert, bl.a. sanering av osteomyelitten og eksisjon av tumor med påfølgende rekonstruksjon, eller leggamputasjon. Pasienten ble diskutert med plastisk kirurg. Med bakgrunn i sårets størrelse og lokalisering i trykkutsatt område samt svært dårlige vevs- og hudforhold på leggen opp til kneet ble det vurdert at eksisjon og rekonstruksjon med endebærende fri lapp uten underliggende støtte ikke var et godt alternativ. Samlet sett så man lite mulighet til å bevare en noenlunde funksjonsdyktig ekstremitet, i så fall med fare for tumorresidiv, nye sår og oppbluss av osteomyelitt som risiko.

Pasienten samtykket til en leggamputasjon, som ble gjennomført med $15 \mathrm{~cm}$ bevart tibia $20 \mathrm{~cm}$ fra proksimale sårkant med en bakre lapp til lukking av stumpen. Histologi av amputatet bekreftet et høyt differensiert plateepitelkarsinom svarende til et verrukøst karsinom, med dybdevekst på minst $10 \mathrm{~mm}$, men uten påvist infiltrasjon i fettvev, perinevralt eller i fascie/muskulatur (Figur 5). Diagnosen plateepitelkarsinom ble stilt med antatt stadium T3 No Mo (AJCC-8) (5).

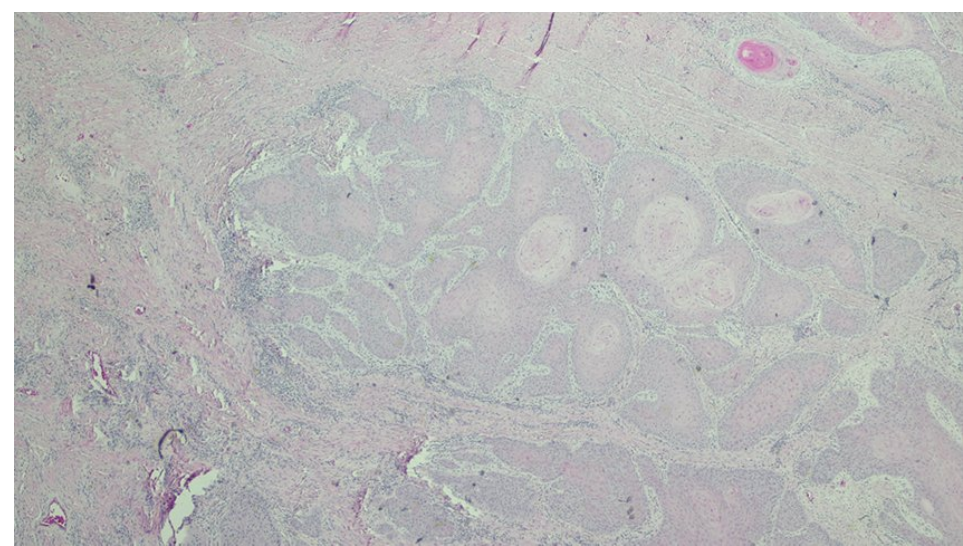

Figur 5 Rutinefarget histologisk snitt (HE) fra tumor viser atypisk endofytisk vekst av høyt differensiert plateepitel, passende med verrukøst karsinom (20× forstørrelse, oppløsning $3264 \times$ 1836). $1151 \times 647 \mathrm{~mm}(72 \times 72 \mathrm{DPI})$.

Postoperativt bidro dårlige hudforhold til en mindre sårruptur, som tilhelte konservativt med vakuumbehandling. Pasienten fikk tilpasset protese og har i etterkant klart å omstille seg fint til bruk av protesen. Han er tilbake i en fysisk krevende jobb, med noen få tilpasninger.

\section{Diskusjon}

Utvikling av hudkreft, særlig plateepitelkarsinom, er en kjent komplikasjon ved kronisk inflammatoriske tilstander og er ofte assosiert med kroniske sår, tidligere traumatisert vev og arrvev. Eponymet Marjolins ulcus brukes som betegnelse på denne typen malignitetsutvikling. Insidens er anført til mellom 1 og $2 \%(6,7)$ med høyest forekomst blant pasienter med tidligere brannskade, etterfulgt av traumatiske sår, venøse sår, osteomyelitt og trykksår $(8,9)$. Andre kronisk inflammatoriske tilstander som bl.a. hidradenitis suppurativa er også kjent å kunne gjennomgå malignitetsutvikling (10). De fleste publikasjoner som omhandler Marjolins ulcus gjelder kasuistikker, særlig fra utviklingsland, der pasienter oftere har begrenset tilgang til helsetjenester. Når diagnostikk og behandling uteblir, søker pasientene helsehjelp med langtkommet og behandlingsrefraktær sykdom $(8,11)$. Malignitetsutvikling er hyppigst rapportert på underekstremiteter, men sees også på overekstremiteter, truncus og i hode-hals-området (6). Gjennomsnittlig tid fra primær vevsskade til malignitetsutvikling er anført til 30 år med en gjennomsnittsalder hos pasientene på 50 år $(7,12,13)$.

Patogenesen er kompleks og er knyttet til en rekke immunologiske, genetiske og 
miljørelaterte faktorer, bl.a. tumorsuppressorgener, proliferasjonsmarkører, antiapoptotiske proteiner, humant papillomavirus og UV-stråling (12).

Kronisk inflammasjon i og rundt kroniske sår kan føre til økt celledeling og dermed økt fare for spontane mutasjoner. Toksiner fra nekrotisk vev, spesielt ved brannskader, har vist å ha en mutagen effekt (13). Det er også påvist mutasjoner i gener som er ansvarlige for celledeling og apoptose (14). I ikke-helende sår fører immunologiske prosesser til redusert matriks metalloproteaseaktivitet og kollagendannelse, en mekanisme som igjen fremmer dannelse av fibrotisk vev. I fibrotiske områder er immunsystemets funksjon redusert på grunn av avaskulært vev og obstruksjon av lymfekar. Dette kan føre til at maligne celler ikke oppdages og ikke elimineres av immuncellene. I skjøre og adherente arr etter tidligere skade finner man også redusert elastisitet og lite underliggende subkutant vev som huden kan gli over. Huden utsettes da lettere for gjentatt irritasjon gjennom friksjon og traume.

Den vanligste hudkrefttypen ved Marjolins ulcus er et høyt differensiert plateepitelkarsinom, men ofte av en mer aggressiv natur og med et større metastatisk potensial og høyere residivrate enn plateepitelkarsinom av annen etiologi $(8,9,15)$. I en metaanalyse basert på 412 brannskadde pasienter fra årene 1923 til 2004 så man hyppigst utvikling til plateepitelkarsinom (71\%), dernest basalcellekarsinom (12\%) og melanom (6\%), samt sarkomer og andre neoplasier (12). I en fransk studie av kroniske leggsår som hadde progrediert til tross for tre måneder eller mer med adekvat behandling, fant man malignitet i rundt $10 \%$ (16). I en serie med rundt 35 ooo pasienter med keratinocyttkarsinom (hudkreft av ikke-melanomtype) på ekstremiteter fant man 1208 plateepitelkarsinomer, hvorav 41 hadde en klar historikk med forutgående brannskade eller stråledermatitt. Metastasering forekom totalt hos 1,4\%, men hos hele $44 \%$ av pasientene med forutgående vevsskade (17). I ovennevnte metaanalyse fant man regionale metastaser hos $22 \%$ og fjernmetastaser hos $14 \%$ med malignitetsutvikling i arr etter forutgående brannskade (12).

Biopsi anbefales ved alle kroniske sår som ikke viser fremgang under adekvat sårbehandling etter tre måneder eller mer $(13,16)$. Det anbefales å ta flere stansebiopsier, både fra sårets senter og kant (18). Ved kliniske infeksjonstegn kan det være aktuelt å ta bakteriologiske prøver. Gule stafylokokker er det dominerende patogenet i ikke-helende sår, men er heller sjeldent i sår med malignitetsutvikling. Dette taler for at malignitet kan ha en inhibitorisk effekt på bakterievekst (19).

Hos pasienter med malignitetsutvikling i kroniske sår over eksponert benvev, slik som ved dekubitalsår eller på ekstremiteter, anbefales radiologisk utredning for vurdering av eventuell underliggende osteomyelitt. Vanlig røntgenundersøkelse kan vise tegn til periostal reaksjon eller bendestruksjon. Magnetisk resonanstomografi viser hvor mye underliggende vev som er involvert, og kan bidra til vurdering av reseksjonsgrenser ved kirurgisk behandling (20). MR-undersøkelse vil også bidra til å foreta en riktig stadieinndeling av tumor.

Det finnes ingen etablert behandlingsprotokoll for kreft utviklet fra kroniske sår, og valg av behandling må vurderes ut ifra tumors klassifikasjon og differensieringsgrad. Litteraturen om plateepitelkarsinomer i forbindelse med osteomyelitt omfatter kun oversiktsartikler med et lite antall pasienter og gir derfor ikke noe klart svar om hvilken behandling som bør velges. Målet med enhver behandling må være å kurere tumorsykdommen samt sanere eventuelle infeksjoner.

Muligheten for ekstremitetsbevarende kirurgi vil være avhengig av affeksjon av underliggende strukturer, pasientens funksjonsnivå og rehabiliteringspotensial. I de fleste tilfeller vil behandlingen være eksisjon av tumor og dekning av defekten med bruk av hudtransplantater eller egnet lappeplastikk. Valg av eksisjonsmargin ved kirurgisk behandling av plateepitelkarsinomer er et omdiskutert tema. Det finnes flere publiserte retningslinjer, bl.a. fra USA (21). I en studie basert på bruk av Mohs' mikrografiske kirurgi, som gir en høy sikkerhet for frie marginer, fant man at med en margin på 13,25 $\mathrm{mm}$ ville $95 \%$ 
av høy-risiko-plateepitelkarsinomer være eksidert radikalt (22). Det er ofte vanskelig å makroskopisk definere tumors avgrensning før opptegning av eksisjonsmarginer. Dette og andre faktorer, slik som lokalisasjon av tumor, funksjon og kosmetiske hensyn, gjør at det alltid må gjøres en individuell vurdering av hvert kasus.

Indikasjon for amputasjon er avhengig av lokale, histologiske og radiologiske funn, samt en vurdering av pasientens forventede funksjonsevne etter inngrepet. Amputasjon har tidligere vært anbefalt pga. ønske om radikalitet, men vevssparende og ekstremitetsbevarende kirurgi brukes stadig mer (23). I noen tilfeller vil man stå overfor store bendefekter som truer stabiliteten i rørknoklene. I slike situasjoner er det foreslått å fylle defekten med et bentransplantat og bruke ekstern fiksasjon til temporær stabilisering (24).

Nytten av vaktpostlymfeknutebiopsi er ikke dokumentert. Arrvev med obstruerte lymfekar kan være årsak til at denne prosedyren ikke gir de samme resultatene som ved andre krefttyper (24). Profylaktisk lymfeknutedisseksjon anbefales ikke (16). Ikke-operative behandlingsopplegg omfatter strålebehandling, men det finnes ingen entydig anbefaling om hvilke pasienter som skal få slik behandling. Det er anbefalt stråling av lesjoner som er større enn ti cm i diameter (15). Andre har anbefalt strålebehandling først og fremst for pasienter med basalcellekarsinom (9). Det ser imidlertid ut til at strålebehandling og kjemoterapi skal forbeholdes palliative situasjoner som ved inoperabilitet, metastaser og når pasienten motsier seg kirurgisk behandling $(15,25)$.

Det finnes ingen etablerte oppfølgingsrutiner, men det anbefales ofte livslang oppfølging (15). I de fleste tilfeller vil dette være tilsvarende som hos pasienter med et plateepitelkarsinom med høy risiko for spredning (5).

Denne kasuistikken er en påminnelse om at kreft, særlig plateepitelkarsinom, kan oppstå i kroniske sår. Hos denne pasienten var det kliniske bildet komplisert av omfattende vevsforandringer etter skade og operasjon i barndommen og en samtidig osteomyelitt, der man til slutt anså amputasjon som beste behandlingsalternativ.

LITTERATUR:

1. Sedlin E, Flemming J. Epidermoid carcinoma arising in chronic osteomyelitis foci. J Bone Joint Surg 1963; 45: 827-38. [CrossRef]

2. Hannah CE, Weig EA, Collier S et al. Verrucous carcinoma: An unexpected finding arising from a burn scar. JAAD Case Rep 2019; 5: 225-7. [PubMed][CrossRef]

3. Elder DE, Massi D, Scolyer RA et al. WHO Classification of Skin Tumours 4th Edition. IARC Publication, 2018.

4. Calonje E, Brenn T, Lazar AJ et al. McKee’s Pathology of the Skin 5th Edition. Elsevier, 2019.

5. Eighth Edition of the American Joint Committee on Cancer Staging Guidelines. American Joint Committee on Cancer Staging, 1997.

6. Copcu E. Marjolin's ulcer: a preventable complication of burns? Plast Reconstr Surg 2009; 124: 156e-64e. [PubMed][CrossRef]

7. Bazaliński D, Przybek-Mita J, Barańska B et al. Marjolin's ulcer in chronic wounds - review of available literature. Contemp Oncol (Pozn) 2017; 21: 197-202. [PubMed][CrossRef]

8. Kerr-Valentic MA, Samimi K, Rohlen BH et al. Marjolin's ulcer: modern analysis of an ancient problem. Plast Reconstr Surg 2009; 123: 184-91. [PubMed][CrossRef]

9. Baldursson BT, Hedblad MA, Beitner H et al. Squamous cell carcinoma complicating chronic venous leg ulceration: a study of the histopathology, course and survival in 25 patients. Br J Dermatol 1999; 140:1148-52. [PubMed][CrossRef]

10. Yon JR, Son JD, Fredericks C et al. Marjolin's ulcer in chronic hidradenitis suppurativa: A rare complication of an often neglected disease. J Burn Care Res 2017;38: 121-4. [PubMed][CrossRef] 
11. Chalya PL, Mabula JB, Rambau P et al. Marjolin's ulcers at a university teaching hospital in

Northwestern Tanzania: a retrospective review of 56 cases. World J Surg Oncol 2012; 10:38.

[PubMed][CrossRef]

12. Kowal-Vern A, Criswell BK. Burn scar neoplasms: a literature review and statistical analysis. Burns 2005; 31: 403-13. [PubMed][CrossRef]

13. Reich-Schupke S, Doerler M, Wollina U et al. Plattenepithelkarzinome in chronischen venösen Ulcera crurum. Daten aus dem deutschen Marjolin-Register und Übersichtsdarstellung. JDDG 2015; 13: 1006-14. [CrossRef]

14. Sinha S, Su S, Workentine M et al. Transcriptional analysis reveals evidence of chronically impeded ECM turnover and epithelium-to-mesenchyme transition in scar tissue giving rise to Marjolin's ulcer. J Burn Care Res 2017; 38: e14-22. [PubMed][CrossRef]

15. Yu N, Long X, Lujan-Hernandez JR et al. Marjolin’s ulcer: a preventable malignancy arising from scars. World J Surg Oncol 2013; 11: 313. [PubMed][CrossRef]

16. Senet P, Combemale P, Debure C et al. Malignancy and chronic leg ulcers: the value of systematic wound biopsies: a prospective, multicenter, cross-sectional study. Arch Dermatol 2012;148: 704-8. [PubMed][CrossRef]

17. Ames FC, Hickey RC. Squamous cell carcinoma of the skin of the extremities. Int Adv Surg Oncol 1980; 3: 179-99. [PubMed]

18. Baldursson B, Sigurgeirsson B, Lindelöf B. Venous leg ulcers and squamous cell carcinoma: a largescale epidemiological study. Br J Dermatol 1995; 133: 571-4. [PubMed][CrossRef]

19. Ogawa B, Chen M, Margolis J et al. Marjolin's ulcer arising at the elbow: a case report and literature review. Hand (N Y) 2006; 1: 89-93. [PubMed][CrossRef]

20. Chiang KH, Chou AS, Hsu YH et al. Marjolin's ulcer: MR appearance. AJR Am J Roentgenol 20o6; 186: 819-20. [PubMed][CrossRef]

21. NCCN Guidelines for patients. Squamous cell skin cancer. (Version 2. Plymouth Meeting, PA: The National Comprehensive Cancer Network, 2020.

https://www.nccn.org/patients/guidelines/content/PDF/squamous_cell-patient.pdf Lest 23.2.2021.

22. Schell AE, Russell MA, Park SS. Suggested excisional margins for cutaneous malignant lesions based on Mohs micrographic surgery. JAMA Facial Plast Surg 2013; 15: 337-43. [PubMed][CrossRef]

23. Xiang F, Song HP, Huang YS. Clinical features and treatment of 140 cases of Marjolin's ulcer at a major burn center in southwest China. Exp Ther Med 2019; 17:3403-10. [PubMed][CrossRef]

24. Bauer T, David T, Rimareix F et al. Ulcère de Marjolin sur ostéite chronique: diagnostic et résultats du traitement: 7 cas. Rev Chir Orthop Repar Appar Mot 2007; 93: 63-71. [PubMed][CrossRef]

25. Pekarek B, Buck S, Osher L. A comprehensive review on Marjolin's ulcus: diagnosis and treatment. J Am Col Certif Wound Spec 2011;3: 6o-4. [PubMed][CrossRef]

Publisert: 28. juni 2021. Tidsskr Nor Legeforen. DOI: 10.4045/tidsskr.20.0730

Mottatt 12.9.2020, første revisjon innsendt 28.12.2020, godkjent 23.2.2021.

(C) Tidsskrift for Den norske legeforening 2020. Lastet ned fra tidsskriftet.no 